\title{
Safety Assessment of Ionic Liquid-Based Lithium-Ion Battery Prototypes
}

\author{
J. Kalhoff1 , G.-T. Kim², S. Passerini ${ }^{2 *}$, G. B. Appetecchi ${ }^{3 *}$ \\ ${ }^{1}$ Institute of Physical Chemistry, University of Muenster, Muenster, Germany \\ ${ }^{2}$ Helmholtz Institute Ulm-Karlsruhe Institute of Technology, Ulm, Germany \\ ${ }^{3}$ ENEA, Agency for New Technologies, Energy and Sustainable Economic Development, SSPT-PROMAS-MATPRO, \\ Rome, Italy \\ Email: "stefano.passerini@kit.edu, "gianni.appetecchi@enea.it
}

Received 26 December 2015; accepted 15 March 2016; published 18 March 2016

Copyright (C) 2016 by authors and Scientific Research Publishing Inc.

This work is licensed under the Creative Commons Attribution International License (CC BY). http://creativecommons.org/licenses/by/4.0/

(c) (i) Open Access

\begin{abstract}
In this paper we report the results of combined cycle- and life-aging and abuse tests carried out under severe conditions on $\mathrm{Li}_{4} \mathrm{Ti}_{5} \mathrm{O}_{12} / \mathrm{LiFePO}_{4}$ lithium-ion stacked prototypes using a PYR 14 FSILiTFSI ionic liquid electrolyte. No relevant degradation phenomena took place within ionic liquid electrolyte during prolonged inactivity period or overcharging. No fire/explosion or venting event as well as no gas development occurred during abuse tests, which led only to modest raise in temperature. Therefore, electrodes based on $\mathrm{Li}_{4} \mathrm{Ti}_{5} \mathrm{O}_{12}$ and $\mathrm{LiFePO}$ active materials can be favorably combined with non-volatile and non-flammable pyrrolidinium FSI ionic liquid electrolytes to realize highly safe lithium-ion battery systems.
\end{abstract}

\section{Keywords}

Ionic Liquids, Lithium-Ion Battery Prototype, Abuse Tests

\section{Introduction}

Present lithium battery systems use electrolytes based on organic solvents, which represent a major safety problem [1]-[4]. In fact, the presence of flammable and volatile organics can lead to dangerous events such as heat generation, thermal runaway, cell venting, fire and, therefore, rapid cell disassembly. For instance, uncontrolled heat development might cause combustion of the vaporized organic electrolyte with oxygen becoming available from the decomposition of the positive electrode [5] [6], leading to catastrophic events (explosion). In addition, the electrolyte burning causes decomposition of the lithium salt, $\mathrm{LiPF}_{6}$, and the PVdF-based electrode binder [7],

${ }^{*}$ Corresponding author.

How to cite this paper: Kalhoff, J., Kim, G.-T., Passerini, S. and Appetecchi, G.B. (2016) Safety Assessment of Ionic LiquidBased Lithium-Ion Battery Prototypes. Journal of Power and Energy Engineering, 4, 9-18. 
leading to development of highly toxic HF gas [8].

Battery manufacturers design systems to deliver specified performance characteristics in safe manner under anticipated usage conditions. However, failure can be caused by poor execution of design, abuse of system usage and unanticipated abuse conditions [9] [10]. Passive and active safeguards [11] have been designed to mitigate or prevent some failures. Major challenges in performance and safety are thermal stability of battery active materials and occurrence of internal short circuits [11]. Therefore, standards and testing protocols have been developed as guidelines on how to assess the safety of lithium-ion batteries [11]-[14].

A very promising approach to overcome the lithium battery safety limitation is represented by the replacement of organic hazardous solvents with non-volatile, non-flammable, thermally stable fluids known as ionic liquids (ILs), e.g., organic/inorganic salts generally molten at room temperature or below [15] [16]. Particularly, ILs based on pyrrolidinium cations and bis(trifluoromethanesulfonyl)imide (TFSI) or bis(fluoromethanesulfonyl) imide (FSI) anions have been successfully proposed for use in lithium batteries [16]-[26].

In the frame of the European project ILLIBATT, we scaled up $\mathrm{Li}_{4} \mathrm{Ti}_{5} \mathrm{O}_{12} / \mathrm{LiFePO}_{4}$ lithium-ion cells using a $\mathrm{PYR}_{14}$ FSI-LiTFSI electrolyte mixture, aiming to realize greener and safer prototypes. The latter, having a nominal capacity of $0.8 \mathrm{~A}$ h, were developed for low to mid-rate applications such as renewable energy storage [27]. The safety level results further enhanced by the use of $\mathrm{Li}_{4} \mathrm{Ti}_{5} \mathrm{O}_{12}$, which does not require any passive layer (SEI) at the anode/electrolyte interface [28], and $\mathrm{LiFePO}_{4}$, because of its resistance to release oxygen (above $225^{\circ} \mathrm{C}$ ) due to the strong bonding to phosphorous [29]. In addition, it should be pointed that the electrodes were made using the fluorine-free, economically viable, natural binder carboxymethylcellulose sodium salt (CMC), this involving the use of water as the only solvent and allowing easier recycle of the battery components at the end of life [25] [26]. In the present paper we report the results obtained from abuse tests on two of these innovative, ionic liquid-based, $\mathrm{Li}_{4} \mathrm{Ti}_{5} \mathrm{O}_{12} / \mathrm{LiFePO}_{4}$ stacked battery prototypes.

\section{Experimental}

\subsection{Battery Prototype Manufacturing}

The $\mathrm{Li}_{4} \mathrm{Ti}_{5} \mathrm{O}_{12} / \mathrm{LiFePO}$ cell components, namely the ionic liquid electrolyte and composite electrodes, were prepared according to procedure routes reported in details elsewhere [25]-[27] [30]. The stacked prototypes were manufactured within a dry-room (relative moisture content $<0.2 \%$ at $20^{\circ} \mathrm{C}$ ), housed in soft packages, evacuated for about $1 \mathrm{~h}$ and, finally, heat-sealed under vacuum.

\subsection{Abuse Test}

Upon manufacturing, two $0.8 \mathrm{~A}$ h class $\mathrm{Li}_{4} \mathrm{Ti}_{5} \mathrm{O}_{12} / \mathrm{LiFePO}_{4}$ stacked prototypes were subjected to two hundreds consecutive charge/discharge full cycles within the $1.0-2.5$ voltage range at $0.1 \mathrm{C}$ current rate, corresponding to $80 \mathrm{~mA}$. The electric tests were performed at $20^{\circ} \mathrm{C} \pm 2^{\circ} \mathrm{C}$ using a Maccor 4000 battery tester. Successively, the fully charged prototypes were stored on a shelf in uncontrolled environment for three years. After this aging period, the batteries were again subjected to 100 full cycles $\left(0.1 \mathrm{C}\right.$ at $\left.20^{\circ} \mathrm{C} \pm 2^{\circ} \mathrm{C}\right)$. Finally, the two cells were fully charged at $0.1 \mathrm{C}$ and, then, subjected to different abuse test types.

The first prototype (ILLIBATT \#1) underwent the nail penetration test (Figure 1, panel A) using a custom designed Abuse Test Chamber (hereinafter called ATC). The abuse test was performed using a $3 \mathrm{~mm}$ diameter steel nail, penetrating the pouch cells perpendicularly with a plunge speed of $80 \mathrm{~mm} \cdot \mathrm{s}^{-1}$. The electric data on the test prototype were collected by a modified 540-R 30 A potentiostat/galvanostat. Additionally, the cell deformation was logged by a high speed camera. IR images referred to internal prototype bulk were taken by Allied Vison Technology IRC 320 infrared camera. Moreover, thermal properties were documented by thermocouples.

The second prototype (ILLIBATT \#2) was overcharged (Figure 1(b)) up to 50\% of the nominal capacity, or $100 \%$ of the capacity $(0.4 \mathrm{~A} \mathrm{~h})$ measured at the $300^{\text {th }}$ charge/discharge full cycle, under a current rate equal to 1C (0.4 A). Therefore, the cell was subjected to an overall charge of $0.8 \mathrm{~A} \mathrm{~h}(200 \%$ SOC with respect to the capacity value detected at the $300^{\text {th }}$ full cycle). As well as for the first prototype, the behavior of ILLIBATT \#2 under overcharge tests was followed by potentiostat/galvanostat, high speed camera and thermocouples. Upon overcharging the prototype ILLIBATT \#2 was discharged down to $1.0 \mathrm{~V}$ and, successively undergone to cycling tests at $0.05 \mathrm{C}$ current rate $(40 \mathrm{~mA})$ and $20^{\circ} \mathrm{C} \pm 2^{\circ} \mathrm{C}$. Table 1 reports the protocol of the overall abuse tests to which the two prototypes were subjected. 

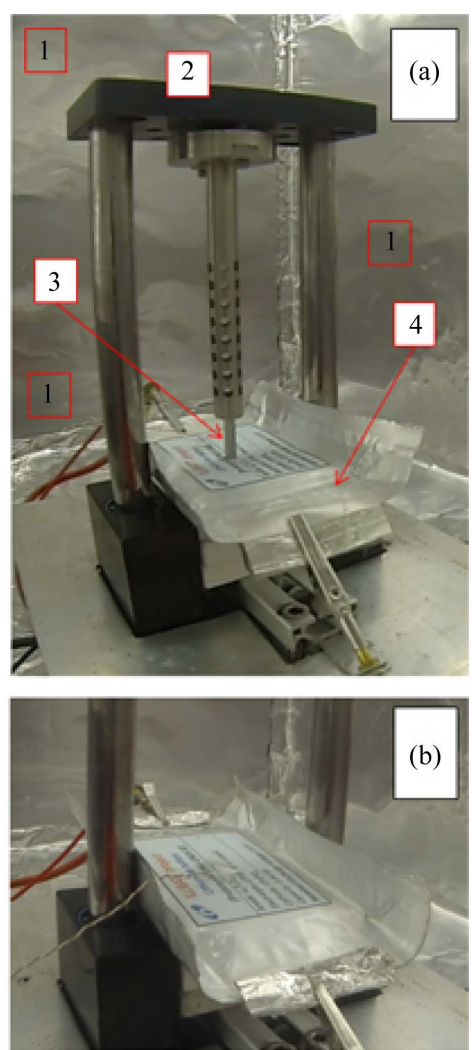

Figure 1. Execution of nail penetration (panel A) and overcharging (panel B) tests on ionic liquid-based, stacked, $\mathrm{Li}_{4} \mathrm{Ti}_{5} \mathrm{O}_{12} / \mathrm{LiFePO}_{4}$ lithium-ion ILLIBATT prototypes. Legend in panel A: 1) abuse test chamber (ATC); 2) abuse test equipment; 3) steel nail; 4) prototype under test.

Table 1. Abuse test protocol carried out on the ILLIBATT battery prototypes.

\begin{tabular}{|c|c|c|}
\hline \multicolumn{3}{|c|}{ Prototype \#1 } \\
\hline Step & Mode & Operating conditions \\
\hline 1 & Charge/discharge cycling & 200 cycles; voltage range: 1.5 - $2.5 \mathrm{~V}$; current: $80 \mathrm{~mA}(0.1 \mathrm{C}) ; \mathrm{T}=20^{\circ} \mathrm{C}$ \\
\hline 2 & Full charge up to $2.5 \mathrm{~V}$ & current: $80 \mathrm{~mA}(0.1 \mathrm{C}) ; \mathrm{T}=20^{\circ} \mathrm{C}$ \\
\hline 3 & Storage in external & 3 years; room temperature \\
\hline 4 & Charge/discharge cycling & 100 cycles; voltage range: 1.5 - $2.5 \mathrm{~V}$; current: $80 \mathrm{~mA}(0.1 \mathrm{C}) ; \mathrm{T}=20^{\circ} \mathrm{C}$ \\
\hline 5 & Full charge up to $2.5 \mathrm{~V}$ & current: $80 \mathrm{~mA}(0.1 \mathrm{C}) ; \mathrm{T}=20^{\circ} \mathrm{C}$ \\
\hline 6 & Nail penetration & steel nail: $3 \mathrm{~mm}$ diameter; plunge speed; $80 \mathrm{~mm} \cdot \mathrm{s}^{-1}$ \\
\hline \multicolumn{3}{|r|}{ Prototype \#2 } \\
\hline Step & Mode & Operating conditions \\
\hline 1 & Charge/discharge cycling & 200 cycles; voltage range: 1.5 - $2.5 \mathrm{~V}$; current: $80 \mathrm{~mA}(0.1 \mathrm{C}) ; \mathrm{T}=20^{\circ} \mathrm{C}$ \\
\hline 2 & Full charge up to $2.5 \mathrm{~V}$ & current: $80 \mathrm{~mA}(0.1 \mathrm{C}) ; \mathrm{T}=20^{\circ} \mathrm{C}$ \\
\hline 3 & Storage in external & 3 years; room temperature \\
\hline 4 & Charge/discharge cycling & 100 cycles; voltage range: 1.5 - $2.5 \mathrm{~V}$; current: $80 \mathrm{~mA}(0.1 \mathrm{C}) ; \mathrm{T}=20^{\circ} \mathrm{C}$ \\
\hline 5 & Full charge up to $2.5 \mathrm{~V}$ & current: $80 \mathrm{~mA}(0.1 \mathrm{C}) ; \mathrm{T}=20^{\circ} \mathrm{C}$ \\
\hline 6 & Overcharge & up to $100 \%$ capacity detected at $300^{\text {th }}$ cycle $(0.4 \mathrm{~A}$ h); current: $0.4 \mathrm{~A}$ \\
\hline 7 & Discharge & $1.0 \mathrm{~V}$; current: $40 \mathrm{~mA} ; \mathrm{T}=20^{\circ} \mathrm{C}$ \\
\hline 8 & Charge/discharge cycling & voltage range: 1.5 - $2.5 \mathrm{~V}$; current: $40 \mathrm{~mA}(0.05 \mathrm{C}) ; \mathrm{T}=20^{\circ} \mathrm{C}$ \\
\hline
\end{tabular}




\section{Results and Discussion}

The fresh-manufactured ILLIBATT lithium-ion prototypes were initially subjected to full charge-discharge cycling tests. The results, reported in Figure 2 as voltage vs discharge capacity profiles, show reproducible flat plateau around 1.8 V, typical of $\mathrm{Li}_{4} \mathrm{Ti}_{5} \mathrm{O}_{12} / \mathrm{LiFePO}_{4}$ cells [25]-[27], with an initial reversible capacity equal or above $0.6 \mathrm{~A}$ h, i.e., exceeding $75 \%$ of the theoretical value. These values are extremely promising considering that the electrodes and the cells were, respectively, manually produced and assembled with simple laboratory equipment. Regarding the cycling tests, a progressive decrease of delivered capacity is observed, particularly upon 30 cycles, even if no substantial change of the voltage profile was detected, this suggesting no practical variation of the nominal discharge voltage and ohmic drop. Capacity values equal to $0.4 \mathrm{~A} \mathrm{~h}$ ( $50 \%$ of the theoretical value) and $0.46 \mathrm{~A} \mathrm{~h}$ (about 60\%) were still delivered after 200 cycles by the ILLIBATT \#1 and ILLIBATT \#2 prototypes (Figure 4), respectively, approaching $68 \%$ and $75 \%$ of the initial values. Also, a coulombic efficiency levelling $100 \%$ upon a few cycles (data not reported) was detected.

The effects resulting from prolonged inactivity periods (e.g., three years) were evaluated by cycling tests. Figure 3 plots the voltage vs capacity profile of selected charge/discharge cycles, which displayed the expected feature for $\mathrm{Li}_{4} \mathrm{Ti}_{5} \mathrm{O}_{12} / \mathrm{LiFePO}$ cells even upon prolonged storage in uncontrolled environment. No relevant variation of the ohmic drop and nominal voltage was observed (during cycling tests) with respect to the freshly manufactured prototypes. This indicates that the ionic liquid electrolyte kept its ion transport properties even

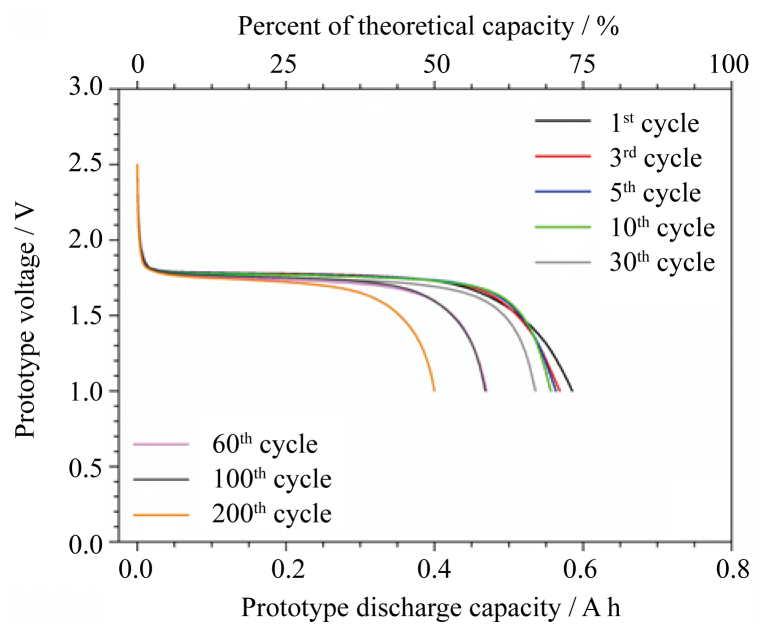

(a)

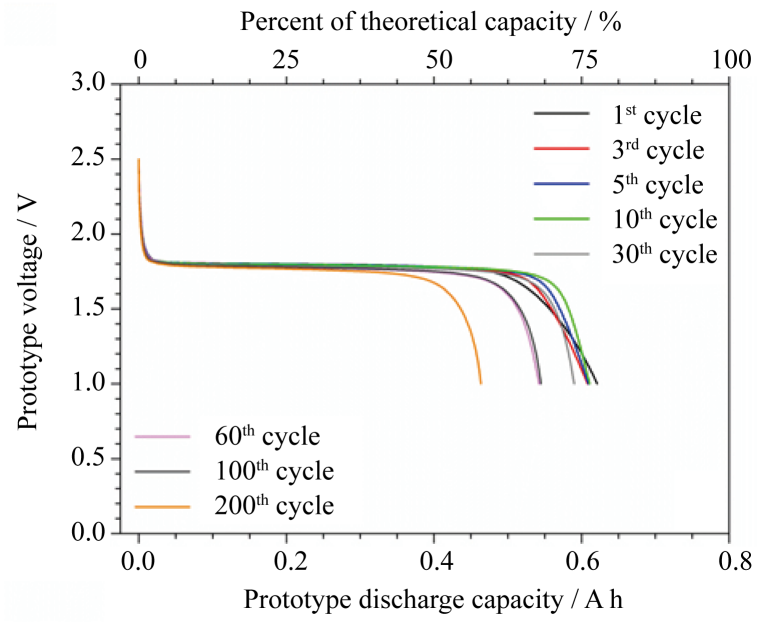

(b)

Figure 2. Voltage vs capacity profile of selected discharge cycles performed $\left(0.1 \mathrm{C}\right.$ at $\left.20^{\circ} \mathrm{C} \pm 2^{\circ} \mathrm{C}\right)$ on fresh-manufactured ILLIBATT \#1 (panel A) and ILLIBATT \#2 (panel B) prototypes. 


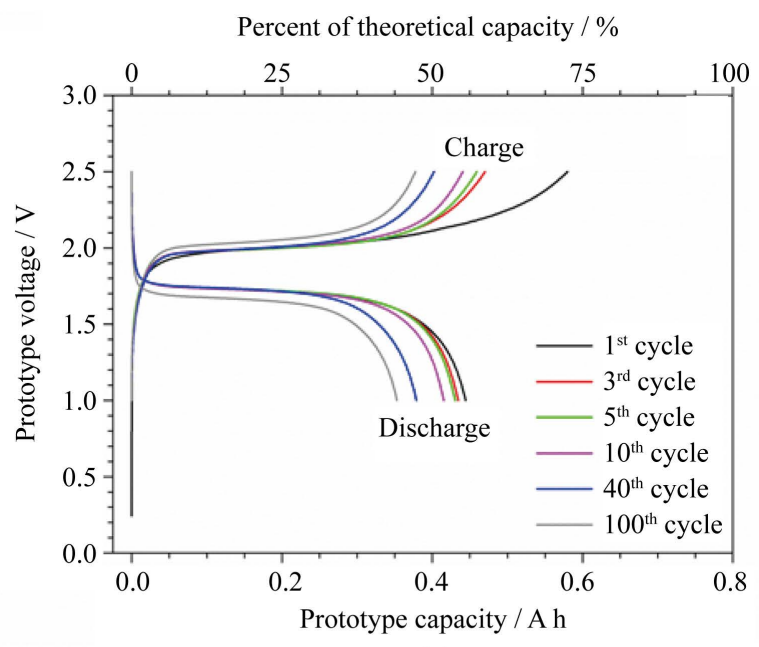

(a)

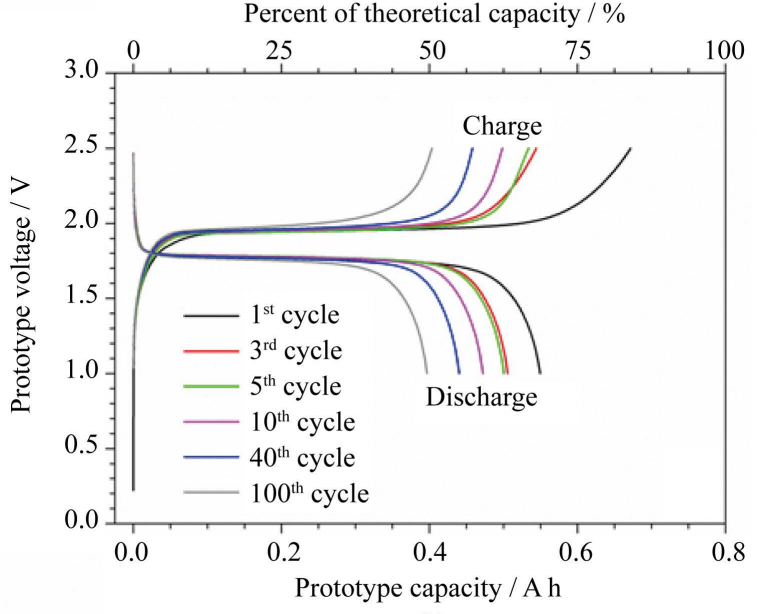

(b)

Figure 3. Voltage vs capacity profile of selected charge/discharge cycles performed $\left(0.1 \mathrm{C}\right.$ at $20^{\circ} \mathrm{C} \pm 2^{\circ} \mathrm{C}$ ) on ILLIBATT \#1 (panel A) and ILLIBATT \#2 (panel B) prototypes after a three year storage period under rest conditions in uncontrolled environment.

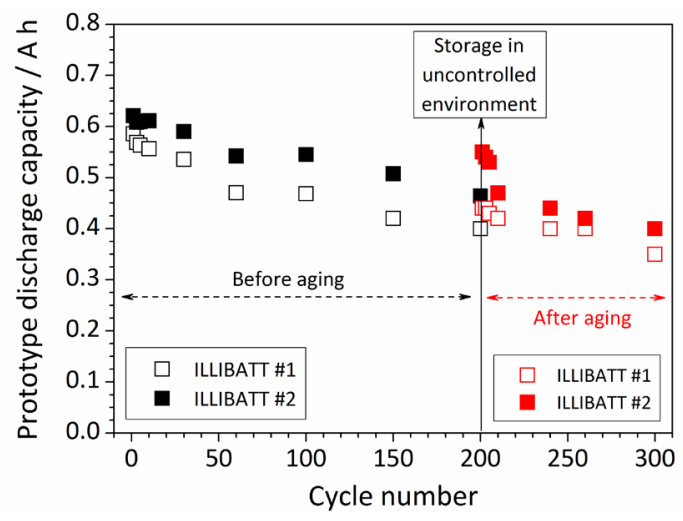

Figure 4. Cycling performance $\left(0.1 \mathrm{C}\right.$ at $\left.20^{\circ} \mathrm{C} \pm 2^{\circ} \mathrm{C}\right)$ of the ILLIBATT \#1 and ILLIBATT \#2 prototypes before (black data markers) and after (red data markers) a three year storage period under rest condition in uncontrolled environment. 
upon prolonged storage of the electrochemical devices and, therefore, no relevant degradation process and/or parasitic reaction regarding the electrolyte components (ionic liquids and lithium salt) took place both under current flow and during rest conditions. The aged prototypes have delivered an initial capacity (see $1^{\text {st }}$ cycle in panels A and B of Figure 3) equal to $0.44 \mathrm{~A}$ h (ILLIBATT \#1 in panel A) and $0.55 \mathrm{~A} \mathrm{~h}$ (ILLIBATT \#2 in panel B), respectively, which were higher than those delivered at the end of the cycling tests $\left(200^{\text {th }}\right.$ cycle in panels A and B of Figure 2) before the three year shelf storage under uncontrolled conditions (Figure 4). This is likely due to ion relaxation phenomena occurring (after prolonged full cycling tests) within the electrolyte and electrodes. Successively, the capacity is seen to decrease down to $0.35 \mathrm{~A} \mathrm{~h}$ (ILLIBATT \#1) and $0.4 \mathrm{~A} \mathrm{~h}$ (ILLIBATT \#2) upon one hundred consecutive full charge-discharge cycles (Figure 4). The initial coulombic efficiency was around $77 \%$, but quickly approaching $100 \%$, as already observed for the freshly assembled prototypes. Therefore, the prolonged inactivity period in uncontrolled conditions does not seem to remarkably affect the reversibility of the lithium intercalation process.

Figure 4 summarizes the cycling behavior results, in terms of discharge capacity evolution, obtained before (black data markers) and after (red data markers) the prolonged storage in uncontrolled conditions. The fresh battery prototypes deliver similar initial capacities, e.g., close to $0.6 \mathrm{~A} \mathrm{~h}$, this is highlighting the more than acceptable reliability of the manual manufacturing procedure. However, ILLIBATT \#2 exhibits better cycling performance (higher capacity retention) than ILLIBATT \#1, showing the lower capacity fade $(0.60 \mathrm{~mA} \mathrm{~h}$, i.e., $0.097 \%$ per cycle, vs $0.95 \mathrm{~mA}$ h, i.e., $0.16 \%$ per cycle) during the initial two hundreds charge-discharge cycles.

After three years shelf-aging, the prototypes initially display an increase of capacity (above $10 \%$ ) with respect to that delivered at the end of the cycling test before shelf-aging. This is highlighted by the comparison between the capacity values obtained from the last cycle before storage (black data markers) and the first one after storage (red data markers). However, after the following few cycles, the capacity evolution of the aged prototypes approached the trend exhibited previously, i.e., showing similar fading. This clearly indicates that no appreciable degradation phenomena occurred for the ionic liquid electrolyte and electrodes during the prolonged storage period. Summarizing, very prolonged inactivity periods (up to three years) in uncontrolled environment do not affect the cycling performance of the ionic liquid-based, $\mathrm{Li}_{4} \mathrm{Ti}_{5} \mathrm{O}_{12} / \mathrm{LiFePO}_{4}$ prototypes.

Before abuse tests (and successively to the cycling tests), the ILLIBATT prototypes were fully charged up to $2.5 \mathrm{~V}(0.1 \mathrm{C})$ as illustrated by the voltage vs time profiles reported in Figure 5. The external cell temperature evolution, recorded during the charge step (data not reported), was found to be rather stable around $22^{\circ} \mathrm{C}$ with a variation lower than $1^{\circ} \mathrm{C}$, which might be likely due to lab temperature change.

The results of the nail penetration tests performed on the ILLIBATT \#1 prototype are depicted in Figure 6. The voltage value (panel A) is seen to sharply decay down to $1 \mathrm{~V}$ as a result of the nail penetration, and, successively, asymptotically achieve $0 \mathrm{~V}$ within a few minutes, indicating short-circuit. It is worthy to point out that no fire (or deflagration) and/or venting as well as no gas development and device deformation/crack were observed during the whole duration of the abuse test (Figure 1), witnessing safety levels not detectable in commercial



Figure 5. Full charge step run on the ILLIBATT \#1 (red trace) and ILLIBATT \#2 (blue trace) prototypes at $0.1 \mathrm{C}\left(20^{\circ} \mathrm{C} \pm 2^{\circ} \mathrm{C}\right)$ before abuse tests. 



Figure 6. Voltage vs time drop (panel a) recorded on the ILLIBATT \#1 prototype during nail penetration test at $20^{\circ} \mathrm{C} \pm 2^{\circ} \mathrm{C}$. The IR camera image (panel b) was taken at the highest temperature after $10 \mathrm{~s}$ penetrating into the prototype.

lithium-ion batteries [9]-[14]. The cell external temperature, monitored during the nail penetration by a IR camera, does not exceed $30^{\circ} \mathrm{C}$ as evidenced by the image depicted in panel B where the warmest zone is highlighted with a dotted circle (it is to note that the IR image was taken at the highest temperature after 10 s penetrating into the cell). This modest temperature raise supports, once more, for the high reliability issues of the ILLIBATT prototypes.

Figure 7 reports the results obtained from overcharging tests performed on the already fully charged prototype ILLIBATT \#2. Despite the overcharge step, causing cell voltage raise up to $6 \mathrm{~V}$ (i.e., more than twice the regular cut-off voltage, $2.5 \mathrm{~V}$ ), as shown by the voltage vs time profile in Figure 7, the external temperature of ILLIBATT \#2 (dotted line) is seen to increase from about $23^{\circ} \mathrm{C}$ (start of overcharge) to $32^{\circ} \mathrm{C}$ (end) e.g., recording a rise of just $7^{\circ} \mathrm{C}$. Apart slight cell inflation, no flame or venting was noticed during the abuse test, as previously observed for ILLIBATT \#1, once more confirming the safety of these ionic liquid-based, lithium battery systems. Upon the overcharge step, the prototype voltage asymptotically decays down to $3.5 \mathrm{~V}$ in less than 1 hour (likely due to relaxation phenomena) whereas the external cell temperature decreases, following an analogous trend, down to slightly above $25^{\circ} \mathrm{C}$. The cycling ability of ILLIBATT \#2 was tested even upon the overcharge step. The results, illustrated as voltage vs time profiles in Figure 8, show a reversible capacity of 70 $\mathrm{mA} \mathrm{h}$ and indicate that the prototype can be cycled afterwards, still delivering $15 \%$ of the initial capacity.

Summarizing, abuse tests have revealed that combining highly reliable $\mathrm{Li}_{4} \mathrm{Ti}_{5} \mathrm{O}_{12}$ and $\mathrm{LiFePO}_{4}$ active material electrodes with non-volatile and non-flammable pyrrolidinium FSI ionic liquid electrolytes results in highly safe lithium-ion battery systems, keeping their safety assessment even in stacked prototypes. 


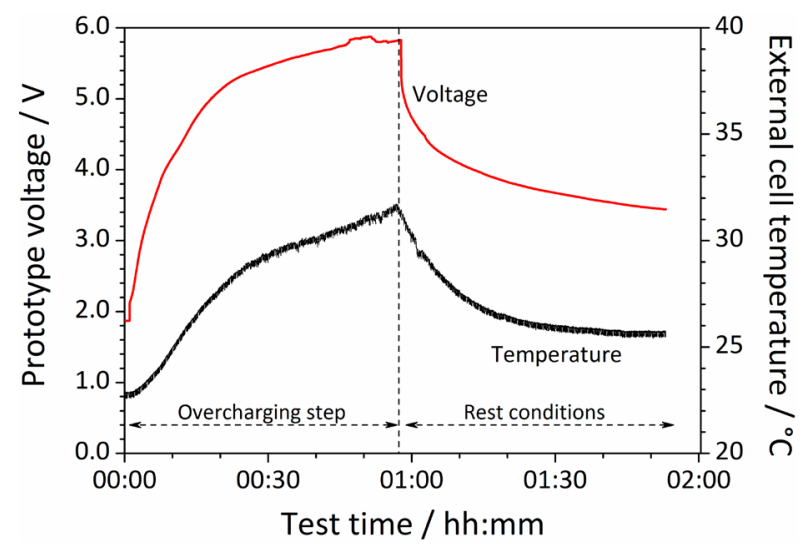

Figure 7. Voltage (red trace) and external temperature (black trace) vs time evolution recorded on $\backslash$ the prototype ILLIBATT \#2 during and upon overcharging test run up to $200 \%$ of the nominal capacity at a current rate equal to $1 \mathrm{C}\left(20^{\circ} \mathrm{C} \pm 2^{\circ} \mathrm{C}\right)$.

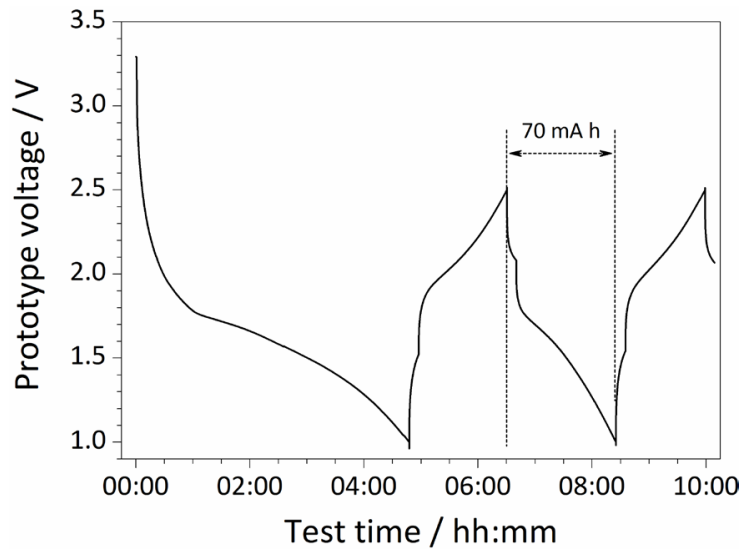

Figure 8. Voltage vs time profile referred to cycling tests run at $0.05 \mathrm{C}$ current rate $(40 \mathrm{~mA})$ on the prototype ILLIBATT \#2 after overcharging test. $\mathrm{T}=20^{\circ} \mathrm{C} \pm 2^{\circ} \mathrm{C}$.

\section{Conclusion}

$\mathrm{Li}_{4} \mathrm{Ti}_{5} \mathrm{O}_{12} / \mathrm{LiFePO}_{4}$ lithium-ion battery prototypes, manufactured in the frame of an European project using a $\mathrm{PYR}_{14}$ FSI-LiTFSI ionic liquid electrolyte, were subjected to combined three-year storage in uncontrolled environment followed by abuse tests (nail penetration and overcharging). The results have revealed that the ionic liquid electrolyte is able to stand prolonged inactivity periods and high voltages without relevant degradation phenomena. No fire/explosion or venting event as well as no gas development occurred during abuse tests even performed under severe conditions, which led only to modest raise in temperature within the prototypes. Therefore, electrodes based on $\mathrm{Li}_{4} \mathrm{Ti}_{5} \mathrm{O}_{12}$ and $\mathrm{LiFePO}_{4}$ active materials can be favorably combined with non-volatile and non-flammable pyrrolidinium FSI ionic liquid electrolytes to realize highly safe lithium-ion battery systems.

\section{Acknowledgements}

The authors gratefully acknowledge the financial support of the European Commission under Contracts NMP3CT-2006-033181 (ILLIBATT project).

\section{References}

[1] Spotnitz, R. and Franklin, J. (2003) Abuse Behavior of High-Power, Lithium-Ion Cells. Journal of Power Sources, 113, 81-100. http://dx.doi.org/10.1016/S0378-7753(02)00488-3 
[2] Yang, H., Amiruddin, S., Bang, H.J., Sun, Y.K. and Prakash, J. (2006) A Review of Li-Ion Cell Chemistries and Their Potential Use as Hybrid Electric Vehicles. Journal of Industrial and Engineering Chemistry, 12, 12-38.

[3] Abraham, D.P., Roth, E.P., Kostecky, R., McCarthy, K., MacLaren, S. and Doughty, D.H. (2006) Diagnostic Examination of Thermally Abused High-Power Lithium-Ion Cells. Journal of Power Sources, 161, 648-657. http://dx.doi.org/10.1016/j.jpowsour.2006.04.088

[4] Bandhauer, T.M., Garimella, S. and Fuller, T.F. (2011) A Critical Review of Thermal Issues in Lithium-Ion Batteries. Journal of the Electrochemical Society, 158, R1-R25. http://dx.doi.org/10.1149/1.3515880

[5] Wang, Q., Ping, P., Zhao, X., Chu, G., Sun, J. and Chen, C. (2012) Thermal Runaway Caused Fire and Explosion of Lithium Ion Battery. Journal of Power Sources, 208, 210-224. http://dx.doi.org/10.1016/j.jpowsour.2012.02.038

[6] Xiang, H.F., Wang, H., Chen, C.H., Ge, X.W., Guo, S., Sun, J.H. and Hu, W.Q. (2009) Thermal Stability of LiPF $6^{-}$ Based Electrolyte and Effect of Contact with Various Delithiated Cathodes of Li-Ion Batteries. Journal of Power Sources, 191, 575-581. http://dx.doi.org/10.1016/j.jpowsour.2009.02.045

[7] Campion, C.L., Li, W. and Lucht, B.L. (2005) Thermal Decomposition of $\mathrm{LiPF}_{6}$-Based Electrolytes for Lithium-Ion Batteries. Journal of the Electrochemical Society, 152, A2327-A2334. http://dx.doi.org/10.1149/1.2083267

[8] Appetecchi, G.B., Montanino, M. and Passerini, S. (2013) Ionic Liquid-Based Electrolytes for High-Energy Lithium Batteries. In: Bridges, N.J., Rogers, R.D. and Vissser, A.E., Eds., Ionic Liquids: Science and Applications, ACS Symposium Series 1117, Oxford University Press, Inc., American Chemical Society, Washington DC.

[9] Wu, M.-S., Julia Chiang, P.-C., Lin, J.-C. and Jan, Y.-S. (2004) Correlation between Electrochemical Characteristics and Thermal Stability of Advanced Lithium-Ion Batteries in Abuse Tests-Short-Circuit Tests. Electrochimica Acta, 49, 1803-1812. http://dx.doi.org/10.1016/j.electacta.2003.12.012

[10] Mikolajczak, C.J., Hayes, T., Megerle, M.V. and Wu, M. (2007) A Scientific Methodology for Investigation of a Lithium-Ion Failure. Proceedings of the IEEE Portable 2007 International Conference on Portable Information Devices, Orlando, 25-29 May 2007, 1-6. http://dx.doi.org/10.1109/PORTABLE.2007.53

[11] Jones, H.P., Chapin, J.T. and Tabaddor, M. (2010) Critical Review of Commercial Secondary Lithium-Ion Battery Safety Standards. Proceedings of the $4^{\text {th }}$ IAASS Conference Making Safety Matter, Huntsville, Alabama, 19-21 May 2010.

[12] Wu, A. and Chapin, J.T. (2009) Blunt Nail Crush Internal Short Circuit Lithium-Ion Cell Test Method. Proceedings of the 2009 NASA Aerospace Battery Workshop, Huntsville, Alabama, 19 November 2009.

[13] Chapin, J.T., Wu, A., Jones, H. and Tabaddor, M. (2010) Overview of Internal Short Circuit Testing for Lithium-Ion Battery Safety Standards. Proceedings of the 2010 NASA Aerospace Battery Workshop, Huntsville, Alabama, 16-18 November 2010.

[14] Yen, K.H., Tabaddor, M., Chiang, Y., Chen, L. and Wang, C. (2010) Estimation of Explosion Pressure for Abused Lithium-Ion Cells. $44^{\text {th }}$ Power Sources Conference, Las Vegas, Nevada, 14-17 June 2010, 15-18.

[15] Rogers, J.R.D. and Seddon, K.R. (2002) Ionic Liquids: Industrial Application to Green Chemistry (ACS Symposium Series 818). American Chemical Society, Washington DC.

[16] MacFarlane, D.R., Meakin, P., Sun, J., Amini, N. and Forsyth, M. (2009) Pyrrolidinium Imides: A New Family of Molten Salts and Conductive Plastic Crystal Phases. The Journal of Physical Chemistry B, 103, 4164-4170. http://dx.doi.org/10.1021/jp984145s

[17] Appetecchi, G.B., Montanino, M., Zane, D., Carewska, M., Alessandrini, F. and Passerini, S. (2009) Effect of the Alkyl Group on the Synthesis and the Electrochemical Properties of $N$-Alkyl- $N$-methylpyrrolidinium Bis(trifluoromethansulfonyl)imide Ionic Liquids. Electrochimica Acta, 54, 1325-1332. http://dx.doi.org/10.1016/j.electacta.2008.09.011

[18] Zhou, Q., Henderson, W.A., Appetecchi, G.B., Montanino, M. and Passerini, S. (2008) Physical and Electrochemical Properties of $N$-Alkyl- $N$-Methylpyrrolidinium Bis(fluorosulfonyl)imide Ionic Liquids: PY13FSI and PY14FSI. The Journal of Physical Chemistry B, 112, 13577-13580. http://dx.doi.org/10.1021/jp805419f

[19] Paillard, E., Zhou, Q., Henderson, W.A., Appetecchi, G.B., Montanino, M. and Passerini S. (2009) Electrochemical and Physicochemical Properties of PY14FSI-Based Electrolytes with LiFSI. Journal of the Electrochemical Society, 156, A891-A896. http://dx.doi.org/10.1149/1.3208048

[20] Appetecchi, G.B., Montanino, M., Balducci, A., Lux, S.F., Winter, M. and Passerini, S. (2009) Lithium Insertion in Graphite from Ternary Ionic Liquid-Lithium Salt Electrolytes. I. Electrochemical Characterization of the Electrolytes. Journal of Power Sources, 192, 599-605. http://dx.doi.org/10.1016/j.jpowsour.2008.12.095

[21] Lux, S.F., Schmuck, M., Appetecchi, G.B., Passerini, S., Winter, M. and Balducci, A. (2009) Lithium Insertion in Graphite from Ternary Ionic Liquid-Lithium Salt Electrolyte. II. Evaluation of Specific Capacity and Cycling Efficiency and Stability at Room Temperature. Journal of Power Sources, 192, 606-611.

http://dx.doi.org/10.1016/j.jpowsour.2009.02.066 
[22] Guerfi, A., Duchesne, S., Kobayashi, Y., Vijh, A. and Zaghib, K. (2008) $\mathrm{LiFePO}_{4}$ and Graphite Electrodes with Ionic Liquids Based on Bis(fluorosulfonyl)imide (FSI) ${ }^{-}$for Li-Ion Batteries. Journal of Power Sources, 175, 866-873. http://dx.doi.org/10.1016/j.jpowsour.2007.09.030

[23] Sugimoto, T., Atsumi, Y., Kikuta, M., Ishiko, E., Kono, M. and Ishikawa, M. (2009) Ionic Liquid Electrolyte Systems Based on Bis(fluorosulfonyl)imide for Lithium-Ion Batteries. Journal of Power Sources, 189, 802-805. http://dx.doi.org/10.1016/j.jpowsour.2008.07.053

[24] Matsumoto, H., Sakaebe, H., Tatsumi, K., Kikuta, M., Ishiko, E. and Kono, M. (2006) Ionic Liquid Electrolyte Systems Based on Bis(fluorosulfonyl)imide for Lithium-Ion Batteries. Journal of Power Sources, 160, 1308-1313. http://dx.doi.org/10.1016/j.jpowsour.2006.02.018

[25] Kim, G.-T., Jeong, S.S., Joost, M., Rocca, E., Winter, M., Passerini, S. and Balducci, A. (2011) Use of Natural Binders and Ionic Liquid Electrolytes for Greener and Safer Lithium-Ion Batteries. Journal of Power Sources, 196, 2187-2194. http://dx.doi.org/10.1016/j.jpowsour.2010.09.080

[26] Lux, S.F., Schappacher, F., Balducci, A., Passerini, S. and Winter, M. (2010) Low Cost, Environmentally Benign Binders for Lithium-Ion Batteries. Journal of the Electrochemical Society, 157, A320-A325. http://dx.doi.org/10.1149/1.3291976

[27] Kim, G.-T., Jeong, S.S., Xue, M.-Z., Balducci, A., Winter, M., Passerini, S., Alessandrini, F. and Appetecchi, G.B. (2012) Development of Ionic Liquid-Based Lithium Battery Prototypes. Journal of Power Sources, 199, 239-246. http://dx.doi.org/10.1016/j.jpowsour.2011.10.036

[28] Mun, J., Jung, Y.S., Yim, T., Lee, H.Y., Kim, H.-J., Kim, Y.G. and Oh, S.M. (2009) Electrochemical Stability of Bis(trifluoromethanesulfonyl)imide-Based Ionic Liquids at Elevated Temperature as a Solvent for a Titanium Oxide bronze Electrode. Journal of Power Sources, 194, 1068-1074. http://dx.doi.org/10.1016/j.jpowsour.2009.05.048

[29] Joachin, H., Kaun, T.D., Zaghib, K. and Prakash, J. (2009) Electrochemical and Thermal Studies of Carbon-Coated $\mathrm{LiFePO}_{4}$ Cathode. Journal of the Electrochemical Society, 156, A401-A406. http://dx.doi.org/10.1149/1.3106121

[30] Appetecchi, G.B., Scaccia, S., Tizzani, C., Alessandrini, F. and Passerini, S. (2006) Synthesis of Hydrophobic Ionic Liquids for Electrochemical Applications. Journal of the Electrochemical Society, 153, A1685-A1691. http://dx.doi.org/10.1149/1.2213420 